\title{
CORRESPONDENCE
}

\author{
SOME COMMENTS ON THE TILLITE FROM THE BUEM \\ FORMATION OF UPPER PRECAMBRIAN AGE, FROM THE \\ VOLTA REGION OF GHANA, WEST AFRICA
}

SIR,-During the mapping of Field Sheet 182 (Scale $1: 62,500$ ) in the Volta Region of Ghana, for the Ghana Geological Survey, in 1961-62, the author was able to re-examine some of the rocks described as " tillite" from the Buem Formation by Junner $(1936$, p. 14). The term Buem Formation is here used in the sense of Bates (1954, p. 13).

The rocks examined occur east of Nkonya Wurupong (Lat. $7^{\circ} 10 \frac{1}{2}^{\prime} \mathrm{N}$., Long. $0^{\circ} 20 \frac{1}{2}^{\prime}$ E.). This locality is considered to correspond with Junner's locality near Nkonya Wurupong, where he recorded the "tillite" as being in contact with the conglomerates that occur at the junction of Groups B and C (Junner, 1936) of the Buem Formation.

Junner correlated this occurrence with the " tillite" described by Koert (1906, p. 279) from the Buem Formation approximately 60 miles to the north, a correlation which in view of the lack of detailed stratigraphy of the Buem Formation must be considered as being essentially based on lithological character.

Junner (1936, p. 14) described the "tillite" from Koert's type locality as being a "pale greenish argillaceous sandstone containing numerous small isolated angular and sub-angular fragments of biotite-granite, muscovitegranite and hornblende-granite, quartzite, bleached Buem sandstone, Buem greywacke and arkose, limestone, phyllite, mica schist and greywacke". Junner also recorded a striated boulder in the "tillite" from the type locality, which has not been preserved. The author was unable to confirm this critical observation.

Recent reappraisals of the so-called "tillites" (e.g. Schermerhorn and Stanton, 1963 and discussion) appear to call for a reconsideration of the Buem "tillite" especially in view of the failure, during re-examination, to confirm the presence of striated boulders.

Field observations and subsequent petrographical investigations of the Buem rocks occurring in the area of F.S. 182 have fully confirmed the lithological characters of the formation enumerated by Junner (1936). They include shales, laninated shales, mudstones, greywackes, arkoses, and quartzites. Near the top of the Buem sequence in Ghana jaspers and spilitic lavas, the latter with occasional pillow structures, occur. Thin intermittent limestones are also present at approximately the same horizon as the spilitic lavas. In one of these algal laminated structures were seen.

Thus the lithological evidence strongly supports a sub-aqueous origin, in a geosynclinal environment, for the Buem Formation. Moreover, there is an absence of critical evidence that could be considered as favouring a glacial origin. A submarine mudflow origin would appear to be the most probable explanation for the so-called " tillites " of Koert and Junner and they should be placed in the "tilloid" category of Schermerhorn and Stanton (1963).

In particular the conditions of sedimentation in the West Congo geosyncline as interpreted by Schermerhorn and Stanton (op. cit.) appear in a general way to parallel those operating during the deposition of the Buem Formation, although no time relationship or equivalence is implied.

In the most recent review, Haughton (1963, p. 23) expressed the currently held opinion that the Buem Formation as a whole was deposited in a long narrow NNE to SSW trending miogeosyncline.

In the Ghanaian sequence of the Buem Formation slump structures were not recognized by the author, but it should be noted that Haughton (op. cit.) stated that slump structures characterize the shales and graded bedding the greywackes of the Buem Formation.

The author is indebted to the Director, Ghana Geological Survey, for permission to refer to unpublished information. 


\title{
REFERENCES
}

Bates, D. A., 1954. Report of the Director of the Geological Survey for the year 1952-53. Accra, Gold Coast.

BELL, S. V., 1962. Unpublished report on the Geology of Field Sheet 182. Ghana Geological Survey, Accra, Ghana.

Haughton, S. H., 1963. Stratigraphic History of Africa South of the Sahara. Oliver and Boyd, Edinburgh and London.

JunNer, N. R., 1936. Report on the Geological Survey Department for the Financial Year 1933-36. Accra, Gold Coast.

KoERT, W., 1906. Uber Gold Vorkommen bei Kpandu in Togo. Dtsch. Kolon Blatt, 17, 279.

Schermerhorn, L. J, G., and W. I. Stanton, 1963. Tilloids in the West Congo geosyncline. Quart. J. geol. Soc. Lond., 119 (2), 201-241.

S. V. BeLL.

\author{
Department of Geology, \\ UNIVERSTTY OF KHARTOUM, \\ KHARTOUM, \\ REPUBLIC OF THE SUDAN. \\ 13th June, 1964.
}

\section{CONSOLIDATION OF SEDIMENTS}

SIR,--During consolidation a linear relationship is often found between void ratio $(e)$ and consolidation pressure $(p)$ over a moderate range of pressure. In such cases, rearrangement of the water-ionic complex may be the predominant mechanism involved.

If slipping or breaking of particles is of more importance, it may be postulated that there are in the soil a number $(n)$ of locations, at each of which it is possible for an irreversible volume reducing event to occur, and that, on average, each such event allows the volume $(V)$ to reduce by the same amount, i.e.

$$
\frac{d V}{d n}=A, \text { where } A=\text { constant. }
$$

Since the weaker locations will tend to collapse first, there will be a tendency for the rate of collapse to decrease as consolidation proceeds. At the same time, the ability of the soil structure to bridge points of weakness may increase as these points become fewer and more widely separated. It is therefore postulated that volume-reducing events occur at a rate with stress proportional to their number, i.e.

$$
\frac{d n}{d p}=-B n, \text { where } B=\text { constant. }
$$

It follows that

$$
\log (e-a)=b-c p, \text { where } a, b, \text { and } c \text { are constants }
$$

In the figure, the full line is calculated from equation (1), and the points are experimental results for calcareous ooze, cited by Laughton. ${ }^{1}$ The initial void ratio was 190 per cent, and the lack of agreement at low pressures may be due to closure of cracks in the specimen or to elastic effects.

It is of course possible to generalize this approach to allow for more than one phenomenon (e.g. slipping and breaking) "centered" at different pressures, but this aspect is beyond the scope of the data available at present.

${ }^{1}$ A. S. Laughton: Compaction of ocean sediments. Ph.D Thesis. Cambridge Univ., 1955. 